\title{
Trends in sightings and environmental influences on a coastal aggregation of manta rays and whale sharks
}

\author{
C. A. Rohner ${ }^{1,2,3, *}$, S. J. Pierce ${ }^{1,4,5}$, A. D. Marshall ${ }^{1,5}$, S. J. Weeks ${ }^{2}$, M. B. Bennett ${ }^{6}$, \\ A. J. Richardson ${ }^{3,7,8}$ \\ ${ }^{1}$ Manta Ray \& Whale Shark Research Centre, Marine Megafauna Foundation, Praia do Tofo, Inhambane, Mozambique \\ ${ }^{2}$ Biophysical Oceanography Group, School of Geography Planning and Environmental Management, \\ The University of Queensland, St Lucia, Queensland 4072, Australia \\ ${ }^{3}$ CSIRO Marine and Atmospheric Research, EcoScience Precinct, Dutton Park, Queensland 4102, Australia \\ ${ }^{4}$ All Out Africa Research Unit, PO Box 153, Lobamba, Swaziland \\ ${ }^{5}$ ECOCEAN USA, Praia do Tofo, Inhambane, Mozambique \\ ${ }^{6}$ School of Biomedical Sciences, The University of Queensland, St Lucia, Queensland 4072, Australia \\ ${ }^{7}$ Centre for Applications in Natural Resource Mathematics (CARM), School of Mathematics and Physics, \\ The University of Queensland, St Lucia, Queensland 4072, Australia \\ ${ }^{8}$ The Ecology Centre, School of Biological Sciences, The University of Queensland, St Lucia, Queensland 4072, Australia
}

\begin{abstract}
Sightings of planktivorous elasmobranchs at their coastal aggregation sites are often linked to biological, environmental and temporal variables. Many large planktivorous elasmobranchs are also globally threatened species, so it is necessary to try and separate population trends from environmentally driven, short-term fluctuations. We investigated the influence of environmental variables on sightings of 3 species of planktivorous elasmobranchs off Praia do Tofo, Mozambique: the reef manta ray Manta alfredi, giant manta ray $M$. birostris and whale shark Rhincodon typus. We used 8- (2003 to 2011) and 6-yr (2005 to 2011) logbook data for manta rays and whale sharks, respectively, and constructed a generalised linear model with animal sightings as the response. Predictors included temporal (year, month, time of day), biological (plankton categories), oceanographic (water temperature, time from high tide, current direction and strength and wave height) and celestial (moon illumination) indices. These predictors best fitted reef manta ray sightings, a coastal species with high residency, but less so for the wider-ranging giant manta rays and whale sharks. We found a significant decline in the standardised sightings time series for the reef manta ray $(88 \%)$ and whale shark $(79 \%)$, but not for the giant manta ray.
\end{abstract}

KEY WORDS: GLM · Generalised linear model - Decline - Population trend · Seasonality · Environmental variability $\cdot$ Manta alfredi $\cdot$ Manta birostris $\cdot$ Rhincodon typus

\section{INTRODUCTION}

Planktivorous elasmobranchs comprise 14 species of mainly large sharks and rays from 5 genera. This group includes the 3 focal species of this study: the whale shark Rhincodon typus, reef manta ray Manta alfredi and giant manta ray $M$. birostris. While they differ in some aspects of their ecology, they all feed mainly on zooplankton (Stevens 2007, Nakaya et al. 2008, Sims 2008, Couturier et al. 2012). This reliance on zooplankton strongly links sightings of planktivorous elasmobranchs to environmental variables, as 
the distribution and abundance of their prey respond rapidly to environmental changes (Boucher et al. 1987, Richardson 2008). By contrast, sightings of higher trophic level species are likely to be less directly influenced by physical factors due to gradual weakening of the immediate environmental signals with each step up the food chain.

Manta rays and whale sharks have a tendency to aggregate on a periodic or seasonal basis at specific sub-tropical and tropical locations around the world (Stevens 2007, Kashiwagi et al. 2011). Foraging is the main driver behind some of these aggregations (Wilson et al. 2001, Anderson et al. 2011), although manta rays also aggregate at 'cleaning stations' on reefs where small fishes remove parasites and dead tissue, or at inshore areas to mate at specific times of the year (Marshall \& Bennett 2010a,b). These predictable aggregations have, in some areas, been targeted by fishers or tourism operators (Pravin 2000, Alava et al. 2002). All 3 species in this study are now globally listed as Vulnerable on the IUCN Red List of Threatened Species following significant declines in catches or sightings that have mainly been attributed to targeted fisheries (Norman 2005, Marshall et al. 2011a,c).

The influence of environmental variability on sightings of these highly mobile fishes can complicate the interpretation of trend data. For instance, a decline in whale shark sightings along the eastern coast of South Africa between 1993 and 1998 (Gifford 2001) was included in the successful proposal for listing the species on Appendix II of the Convention on International Trade in Endangered Species (CITES 2002). However, with the benefit of hindsight, the substantial variability in sighting data from this area in summer months (Cliff et al. 2007) and seasonal changes in their oceanic distribution (Sequeira et al. 2012) makes it difficult to attribute these earlier data to a genuine population decline. Even with comparatively robust datasets, such as for whale sharks at Ningaloo Reef in Australia, scientific consensus on population trends has proven difficult to attain due to differences in the underlying assumptions of the models, insufficient data to test which approach is more robust, and the potential influence of environmental variability (Wilson et al. 2001, Meekan et al. 2006, Bradshaw et al. 2007, 2008, Holmberg et al. 2008, 2009, Sleeman et al. 2010a). In another planktivorous elasmobranch, the basking shark Cetorhinus maximus, a steep decline in catches in a target fishery off Achill Island in Ireland between 1947 and 1975 was initially attributed to localised stock depletion (Parker \& Stott 1965). Re-analysis of these data in conjunction with concurrent planktonic copepod abundances at this and other sites led Sims \& Reid (2002) to suggest that the decrease may have resulted from a shift in prey, and hence basking shark distribution, rather than strictly due to population decline from fishing (Sims \& Reid 2002, Sims 2008).

Previous investigations on how environmental variables affect the sightings of planktivorous elasmobranchs have focused primarily on temperature. Whale shark numbers in pelagic surface waters of the western Indian Ocean have been shown to correlate with sea surface temperature (SST) (Sequeira et al. 2012). In coastal waters, SST and wind speed have also been correlated with whale shark numbers in an aerial survey in the Seychelles (Rowat et al. 2009) and SST, chlorophyll a (chl a) concentration and bathymetry were important predictors of whale shark and manta ray abundance off Ningaloo Reef, Australia (Sleeman et al. 2007). At Komodo Marine Park, Indonesia, the vast majority of reef manta rays have been recorded in water temperatures from 25 to $28^{\circ} \mathrm{C}$ and when tidal intensity was highest during new and full moons (Dewar et al. 2008). Further, large-scale factors influencing oceanographic processes, such as the Southern Oscillation Index and wind shear at Ningaloo Reef, or monsoon winds in the Maldives, have been linked to shifts in abundance and distribution of planktivorous elasmobranchs (Wilson et al. 2001, Sleeman et al. 2010a, Anderson et al. 2011). These and other environmental factors thus play a role in explaining sighting trends of manta rays and whale sharks. As planktivorous elasmobranchs are often most threatened at their coastal aggregation sites due to their exposure to shorebased fishing and boating activities, it is important to understand drivers of these aggregations and to determine whether observed fluctuations in sightings correspond to short-term environmental variability or whether they represent long-term trends. Standardising sightings data and taking into account environmental covariates are thus potentially important steps in the conservation management of these species.

Here, we aimed to (1) estimate trends in standardised sightings over time, and (2) define the relationships of environmental, spatial and temporal variables on sightings of reef manta rays, giant manta rays and whale sharks at a coastal aggregation site in southern Mozambique. We used a generalised linear model for each species to determine the relative importance of each environmental variable. We hypo- 
thesise that sightings of these plantkivorous fishes are influenced by specific environmental variables and that resident reef manta rays are influenced more strongly by local variables than are transient giant manta rays and whale sharks.

\section{MATERIALS AND METHODS}

\section{Location}

The study was conducted off Praia do Tofo $\left(23.85^{\circ} \mathrm{S}, 35.54^{\circ} \mathrm{E}\right)$, Inhambane Province, southern Mozambique (Fig. 1). All trips were conducted in a $40 \mathrm{~km}$ stretch of coastal waters. Manta rays aggregate here mainly for cleaning, and they can spend up to $8 \mathrm{~h} \mathrm{~d}^{-1}$ in this activity (Marshall 2009, van Duinkerken 2010). We used SCUBA to observe them at cleaning stations on reefs primarily at Sites 1 and 2 . Less frequently surveyed reefs were combined into 3 'northern reefs', 3 'southern reefs' and 7 'central reefs'. Whale sharks were spotted from boats, with search effort concentrated in coastal waters within $8 \mathrm{~km}$ south of Praia do Tofo (Fig. 1).

\section{Logbook data}

\section{Manta rays}

Manta ray logbook data were recorded by A. D. Marshall. The dataset comprised 855 dives spanning

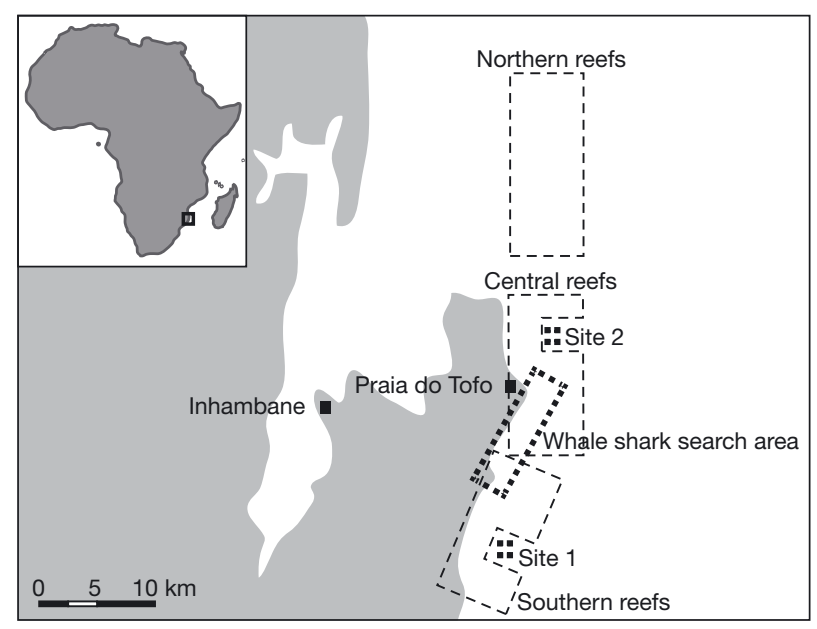

Fig. 1. Study location at Praia do Tofo $\left(23.85^{\circ} \mathrm{S}, 35.54^{\circ} \mathrm{E}\right)$ in southern Mozambique, indicating the dive sites where manta ray sightings were recorded (thin dashed areas) and the survey area for whale sharks sightings (thick dashed area)
8 yr (May 2003 to April 2011). Sightings of reef and giant manta rays were measured as individuals per dive ('raw sightings' henceforth). In terms of sampling effort, data on dive duration (to standardise each dive over the past $8 \mathrm{yr}$ ) was not available. We thus performed a pilot study to assess the influence of dive duration on manta ray sightings. The pilot study included 102 dives over 4 mo in 2012. Dives had a mean duration of $39.3 \mathrm{~min}$ and a relatively small SD of $7.67 \mathrm{~min}$. We found no significant relationship between number of manta rays (response variable) and duration of dive (ANOVA; reef manta ray: $F=1.25, \mathrm{p}=0.265$; giant manta ray: $F=3.07$, $\mathrm{p}=0.085)$. This is likely to be because searches across the reef consistently took the same track over the study period, that manta rays spend most of the day at cleaning stations, and that they are large and conspicuous. Spatial autocorrelation is unlikely to be a major issue for manta rays because the total area of cleaning stations where manta rays congregate and divers searched for them is small $\left(0.5 \mathrm{~km}^{2}\right)$. Manta rays also show some site fidelity to particular cleaning stations over a period of several hours (Marshall 2009) and it is unlikely that the same manta ray will be seen at different sites on closely spaced dives on the same day. Photographic identification allowed individual animals to be distinguished (Marshall et al. 2011b) and those that were spotted multiple times in the same dive were counted once only. Nine predictors were recorded in the logbook, in addition to sightings of reef and giant manta rays (Table 1 ).

To account for temporal influences on manta ray sightings, year, month and time of day were recorded for each dive. Dive site was included as a predictor in the manta ray models because manta rays were observed at 5 different sites. This spatial predictor was used to investigate preferences for certain reefs. As a general index of food availability, the major planktonic component during the dive was visually assessed underwater and grouped into 5 categories: (1) zooplankton (i.e. dense visible zooplankton, such as copepods, pteropods or gelatinous zooplankton present in the water), (2) phytoplankton (i.e. visibly green water), (3) no obvious plankton, (4) suspended sediments (i.e. stirred up sediment reducing visibility) and (5) surface slicks (i.e. plankton forming a slick visible only near the surface). As water temperature has previously been correlated with planktivorous elasmobranchs (Dewar et al. 2008, Rowat et al. 2009, Sequeira et al. 2012), we included in situ temperature $\left(1^{\circ} \mathrm{C}\right.$ intervals) recorded at depth on a dive computer. The same computer was 
used consistently, which provided the same readings as a temperature recorder (Onset Hobo Pro v2 with $\pm 0.2^{\circ} \mathrm{C}$ accuracy) in sporadic assessments. To investigate the influence of physical environmental conditions on manta ray behaviour, current direction (N, E, S, W or absent) and strength (absent, light, medium, strong) were assessed underwater visually in relation to the reef. Underwater visibility, visually estimated horizontally at depth in $1 \mathrm{~m}$ increments, was included to account for potential sightability effects. Moon phase has been shown to influence biorhythms in other fishes (Colin 1992, Agenbag et al. 2003, Heyman \& Kjerfve 2008) and hence moon illumination data were downloaded for the location from NASA's Horizons website (http:// ssd.jpl.nasa.gov/horizons.cgi). Tidal phase and amplitude have also been shown to affect some large planktivores (Dewar et al. 2008) and tide data for Inhambane were obtained from Mobile Geographics (www.mobilegeographics.com).

\section{Whale sharks}

Whale shark logbook data were recorded by S. J. Pierce and C. A. Rohner. Observations were made during 720 trips between January 2005 and April 2011. Whale shark numbers were measured as individuals sighted per boat trip ('raw sightings' henceforth). Similar to the methods of Pierce et al. (2010), searches for whale sharks were conducted from 6.5 to $8.2 \mathrm{~m}$ long rigid-hull inflatable vessels, often with the addition of a raised spotting chair to enlarge the search area. In terms of sampling effort, most (95\%) trips lasted 2 hours ( \pm 15 minutes) because of commercial operational constraints. On each trip, we performed a zig-zag search pattern between the beach and $1 \mathrm{~km}$ offshore, on the south- and northward passes within the 'whale shark area' from Praia do Tofo to $8 \mathrm{~km}$ south (Fig. 1). One 'spotter' constantly scanned the surface for whale sharks. 'Site' was not included in the whale shark model because all whale shark observations were made at one site. Spatial autocorrelation is unlikely to be a major issue for whale sharks because the area was small $\left(\sim 8 \mathrm{~km}^{2}\right)$ and was searched in a consistent way each trip. Individual whale sharks were identified using underwater photographs of the body region immediately posterior to the gills (Arzoumanian et al. 2005). Those that were spotted multiple times in the same trip were counted once only, although there may be some error associated with aggregations of $>10$ sharks $(2.4 \%$ of observations) where not all individuals could be photographed. To account for temporal effects, year, month and time of day were recorded. Moon illumination and tide data were downloaded as described in the manta ray dataset methods. However, as in situ observational plankton data were not recorded for this part of the study, we used remotely-sensed chl $a$ as a proxy for zooplankton in the model. Despite a possible lag time of zooplankton abundance in response to a phytoplankton bloom (Plourde \& Runge 1993, Flagg et al. 1994), phyto- and zooplankton abundance is often correlated (Hutchinson 1967, Richardson \& Schoeman 2004, Ware \& Thomson 2005) and chl a has been used to explain occurrence and movements of marine animals in various studies (Zagaglia et al. 2004, Block et al. 2011), including some on planktivorous elasmobranchs (Sleeman et al. 2007, Graham et al. 2012). Similarly, satellitederived SST was used in the absence of in situ temperature recordings. Chl $a$ and SST data at $1 \mathrm{~km}$ resolution were derived from the Moderate Resolution Imaging Spectroradiometer (MODIS; http:// modis.gsfc.nasa.gov). These data were composited to $5 \mathrm{~d}$ means for the region and extracted for the location off Praia do Tofo $\left(23.893^{\circ} \mathrm{S}, 35.578^{\circ} \mathrm{E}\right)$. Due to cloud contamination, minor temporal interpolation was applied $(<5 \%)$. Surface conditions can affect where and how well whale sharks are visible (Rowat et al. 2009) and we therefore included wave direction and height and wind direction and speed in the initial model. These data were acquired from Buoyweather's hindcast model at $23.85^{\circ} \mathrm{S}, 35.7^{\circ} \mathrm{E}$, $\sim 15 \mathrm{~km}$ off Praia do Tofo (www.buoyweather.com).

\section{Model}

A negative binomial generalised linear model (GLM) with natural splines was constructed using the statistical software R (v.2.13.0; www.r-project. org), with raw sightings set as the response and the aforementioned suite of local variables as predictors (Table 1). Model residuals were visually assessed for normality and homogeneity of variance and an untransformed response with a normal error structure was found to be appropriate. A generalised additive model (GAM; in the mgcv R-package) was used to explore the relationships and define the degrees of freedom (df) to be used for smooth terms in the GLM. This was conservatively set at $\mathrm{df}=3$ for all smooth terms, unless the GAM plots indicated that $\mathrm{df}=4$ or 5 more appropriately defined a relationship. The best model was conservatively 


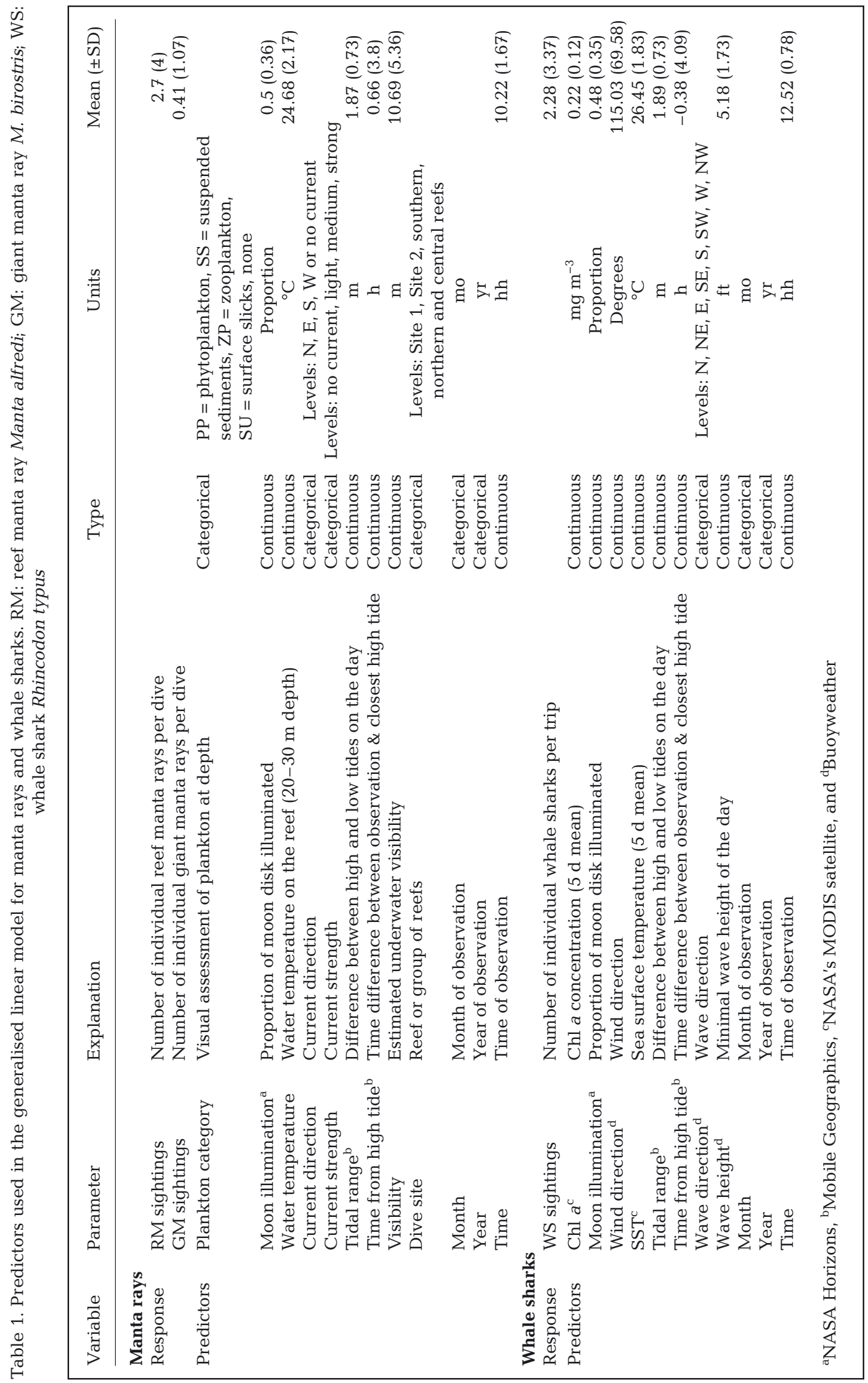


assessed using a stepwise Akaike's Information Criterion (AIC) function with the default penalty per parameter set at $\mathrm{k}=2$ and a dropterm $\chi^{2}$ function was performed on the AIC-supported model. The significance of each predictor on modelled standardised sightings ('sightings' henceforth) in the final model after the AIC selection process was assessed using a $\chi^{2}$ test (Venables \& Ripley 2002). In the model output figures, the $y$-axis is a relative scale, so that a $y$-value of zero is the mean effect of the adjusted predictor on the response, a positive $y$ value indicates a positive effect on the response, and a negative $y$-value indicates a negative effect on the response. If a horizontal line can be placed between the $95 \%$ confidence limits (dotted lines), this implies that the relationship between the response and the predictor is not significant. These lines tend to diverge near the extremes of the range for continuous predictors as a consequence of fewer observations.

Correlations between continuous predictors were assessed with the Pearson method (cut-off $=0.25$ ), and there were no significant correlations between any predictors. Post-hoc Tukey tests were used to perform multiple comparisons among levels of categorical predictors. To estimate \% change in megafauna sightings through time, rather than using estimates from the GLM for the last and first yr which are dependent on 2 yr only, we fitted a line through the annual model estimates. Levels of categorical predictors and values of continuous predictors that resulted in highest animal sightings were used for each predictor. A negative exponential fitted best for all species. We then estimated \% change from the first to last years from these lines of best fit and used an ANOVA to calculate significance.

\section{RESULTS}

\section{Raw sightings}

Raw sightings per unit effort were highest for reef manta rays (mean $\pm \mathrm{SE}=2.7 \pm 0.14$ ind. dive ${ }^{-1}$ ), followed by whale sharks $\left(2.3 \pm 0.13\right.$ ind. trip $\left.^{-1}\right)$ and giant manta rays $\left(0.4 \pm 0.04\right.$ ind. dive $\left.{ }^{-1}\right)$. Interannual variability in raw sightings was high over the study period for all species (Fig. 2). Effort also varied over time, with manta ray searches ranging from 0 to 43 dives $\mathrm{mo}^{-1}$ and whale shark searches ranging from 0 to 28 trips $\mathrm{mo}^{-1}$ (Fig. 2 insets). We partially accounted for this bias by standardising sightings with a GLM.

\section{Overall model}

The final GLM for reef manta rays explained $39.9 \%$ of the total variance (Table 2 ) and had an AIC score of 3226 (model with all predictors: AIC = 3230.0). Ten predictors were retained including year, month, dive site, water temperature, moon illumination, time from high tide, plankton categories, current direction, current strength and time of day (Fig. 3). The final GLM for giant manta rays explained $30.3 \%$ of the total variance and had an AIC score of 1260 (model with all predictors: AIC = 1283.5). Five predictors were retained for giant manta rays (Fig. 4), including year, month, dive site, water temperature and moon illumination. The final GLM for whale sharks explained $23.9 \%$ of the variance and had an AIC score of 2749.7 (model with all predictors: AIC $=2778.4$ ). Four predictors were retained for whale sharks (Fig. 5), including year, month, time from high tide and wave height. The year factor was the most significant predictor for reef manta rays $\left(\chi^{2}=116.0, \mathrm{p}<0.001\right)$ and whale sharks $\left(\chi^{2}=112.1, p<0.001\right)$, accounting for 24.6 and $13.7 \%$ of the variance, respectively. The year factor also explained most $(12.2 \%)$ of the variance for giant manta rays, while dive site $(9.1 \%)$ was the most significant predictor $\left(\chi^{2}=55.0, \mathrm{p}<0.001\right)$. Other strongly significant predictors included water temperature $\left(\chi^{2}=29.8, p<0.001\right)$ and dive site $\left(\chi^{2}=22.5\right.$ $\mathrm{p}<0.001)$ for reef manta rays, month $\left(\chi^{2}=42.3, \mathrm{p}<\right.$ $0.001)$ for giant manta rays, and month $\left(\chi^{2}=68.6, \mathrm{p}<\right.$ $0.001)$ and wave height $\left(\chi^{2}=13.9, p=0.003\right)$ for whale sharks (Table 2).

\section{Inter-annual trends}

Annual standardised sightings from the predictive model showed a steep decline over time for reef manta rays (88\%, ANOVA, $F=23.52, \mathrm{p}=0.002 ; 2003$ to 2011) and whale sharks (79\%, ANOVA, $F=7.39$, $\mathrm{p}=0.042 ; 2005$ to 2011), while sightings of giant manta rays remained relatively stable (ANOVA, $F=$ $1.90, \mathrm{p}=0.21$.

\section{Monthly variation}

Month was a significant predictor in the GLM for all 3 species. Reef manta ray sightings fluctuated over the year (Fig. 3) but a post-hoc Tukey test showed that sightings were only significantly higher in January/February compared to April. Giant 

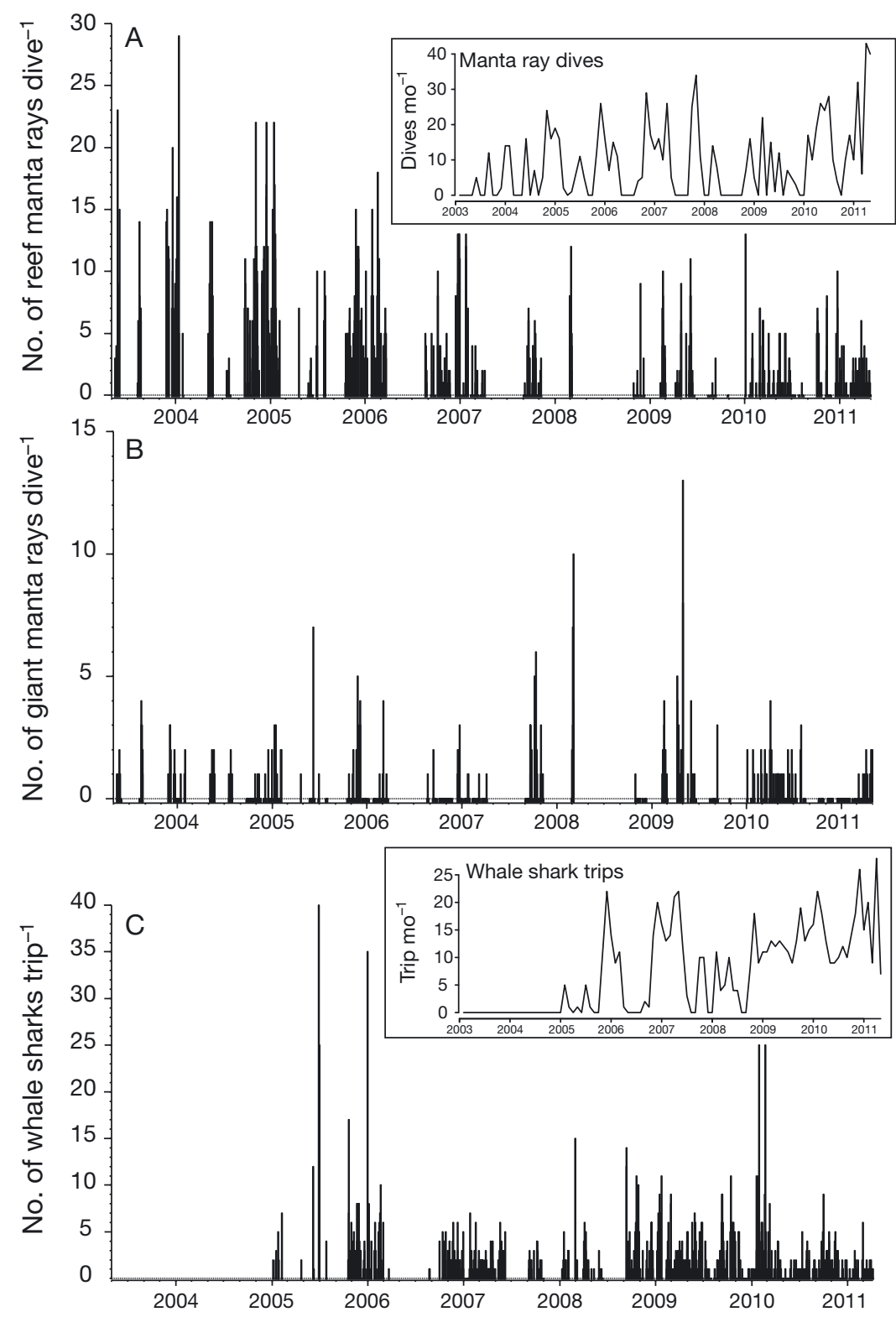

Fig. 2. Manta alfredi, M. birostris and Rhincodon typus. Raw sightings of individual (A) reef manta rays, (B) giant manta rays per dive, and (C) whale sharks per trip, including dives/trips with no sightings (equal to zero). Monthly effort is shown for manta rays (combined) and whale sharks in the insets

\section{Environmental variables}

Water temperature and dive site were strongly significant predictors $\left(\chi^{2}=29.2\right.$ and 23.2, respectively, both $\mathrm{p}<0.001$ ) for reef manta ray sightings. Warmer waters had a positive effect on sightings. More animals were seen at Site 1 than at Site 2, the northern reefs, or southern reefs (Tukey test, $\mathrm{p}<0.03$ ). Reef manta rays were sighted less frequently in northward currents compared to the predominant southward currents, and also when currents were absent $(\mathrm{p}=0.01$ and 0.02 , respectively; Fig. 3). Sighting numbers were lower during strong currents, compared to medium currents ( $\mathrm{p}=0.03$ ), but this was marginally and not significant compared to light and no currents, respectively. More reef manta rays were seen when zooplankton was recorded compared to clear or turbid water conditions $(\mathrm{p}=0.003$ and 0.03, respectively). The model indicated a suggestive trend towards decreasing sightings at $\sim 09: 30 \mathrm{~h}$. Reef manta rays were seen most often during the second quarter of the lunar cycle $(\sim 20$ to $40 \%$ of the moon illuminated). Time from high tide was a significant predictor, but it is difficult to interpret this relationship.

More giant manta rays were observed at Site 1 than at Site 2 and the northern reefs (Tukey test, $\mathrm{p}=$ 0.001 and 0.03, respectively; Fig. 4). Water temperature was significant, but had an inconclusive effect on giant manta ray numbers. Sightings were also higher during the first

manta rays showed a suggestive peak in sightings during April (Fig. 4), which had significantly more sightings than January, February, May, August, October, November and December. Sightings of whale sharks also fluctuated over the course of a year, but showed no clear seasonality. The lower numbers in November and December were significant compared to 5 other months, and the peak in February was significant compared to 4 other months (Fig. 5). quarter of the lunar cycle ( $~ 0$ to $25 \%$ of the moon illuminated), although this predictor was only marginally significant $\left(\chi^{2}=7.8, \mathrm{p}=0.051\right)$.

Wave height was the most significant non-temporal predictor for whale shark sightings $\left(\chi^{2}=13.9, \mathrm{p}=\right.$ 0.003). More sharks were seen when waves were small (Fig. 5). Sightings were at a consistently lower level when waves were $>2 \mathrm{~m}$. Time from high tide was also significant but it was a weak relationship $\left(\chi^{2}=7.9, p=0.048\right)$. 
Table 2. Percentage of variance explained by the GLM and significance values of a $\chi^{2}$ test performed on the AIC-supported models, including marginally significant values $(\mathrm{p}=0.05-0.1)$ in italics

\begin{tabular}{|c|c|c|c|c|c|c|c|c|c|}
\hline \multirow{2}{*}{ Predictors } & \multicolumn{3}{|c|}{${ }_{-}$Reef manta ray } & \multicolumn{3}{|c|}{ _ Giant manta ray } & \multicolumn{2}{|c|}{ _Whale shark } & \multirow[b]{2}{*}{$\mathrm{p}$} \\
\hline & Variance (\%) & $\chi^{2}$ & $\mathrm{p}$ & Variance (\%) & $\chi^{2}$ & $\mathrm{p}$ & Variance $(\%)$ & $\chi^{2}$ & \\
\hline Year & 24.62 & 116.0 & $<0.001$ & 12.16 & 62.6 & $<0.001$ & 13.65 & 112.1 & $<0.001$ \\
\hline Month & 5.60 & 31.5 & 0.001 & 6.30 & 42.3 & $<0.001$ & 7.89 & 68.6 & $<0.001$ \\
\hline Dive site & 1.73 & 23.2 & $<0.001$ & 9.10 & 55.0 & $<0.001$ & - & - & - \\
\hline Water temperature & 1.68 & 29.2 & $<0.001$ & 1.60 & 11.1 & 0.026 & - & - & - \\
\hline Moon illumination & 1.24 & 17.8 & $<0.001$ & 1.13 & 7.8 & 0.051 & - & - & - \\
\hline Time from high tide & 0.21 & 9.6 & 0.022 & - & - & - & 0.80 & 7.9 & 0.048 \\
\hline Plankton categories & 1.69 & 16.5 & 0.003 & - & - & - & - & - & - \\
\hline Current direction & 1.76 & 15.2 & 0.004 & - & - & - & - & - & - \\
\hline Current strength & 0.72 & 7.3 & 0.063 & - & - & - & - & - & - \\
\hline Time & 0.71 & 10.5 & 0.061 & - & - & - & - & - & - \\
\hline Wave height & - & - & - & - & - & - & 1.54 & 13.9 & 0.003 \\
\hline Sum & 39.9 & & & 30.3 & & & 23.9 & & \\
\hline
\end{tabular}

\section{DISCUSSION}

\section{Overall model}

The GLM for reef manta rays retained more variables and explained more of the variance than the models for giant manta rays and whale sharks. While in this study, temporal predictors were significant for all 3 species and the spatial (dive site) predictor only used in the manta ray models was significant for both Manta species, local environmental variables explained sightings of reef manta rays better than for giant manta rays and whale sharks. This may relate to ecological differences within these planktivorous elasmobranchs in terms of the influence local environmental variables have on their sightings, but also with regards to their respective time spent in our study area and their respective sightability.

Reef manta rays were observed predominantly at known cleaning stations (Marshall et al. 2011b), which are also important sites for social behaviours (Marshall \& Bennett 2010b). Although reef manta rays are regularly seen feeding around these reefs, they are not feeding areas per se, but rather multipurpose areas where cleaning is the main behaviour seen by observers. Various cleaning stations are available in the study region and reef manta rays are likely to select favourable environmental conditions to clean in, such as warm water. Reef manta rays are also more strongly resident to the study area than either the giant manta ray or the whale shark (Marshall 2009). Although coastal movements of $\sim 500 \mathrm{~km}$ have been recorded in eastern Australia (Couturier et al. 2011), observations from the Hawaiian islands suggest that relatively small geographic distances over deep waters are not traversed by this species
(Deakos et al. 2011). High site residency of reef manta rays has been observed at the current study site (Marshall et al. 2011b) and elsewhere, including Komodo Island, Indonesia (Dewar et al. 2008) and Maui, Hawaii (Deakos et al. 2011). The relatively high site residency of reef manta rays is likely to be a major reason for why local variables were more important drivers of their sightings compared to sightings of giant manta rays and whale sharks.

In contrast to reef manta rays, giant manta rays and whale sharks are wider-ranging species. While the ecology of the giant manta ray remains poorly known, their seasonal appearance in subtropical and temperate areas such as northern New Zealand (Duffy \& Abbott 2003) and southern Brazil (Luiz et al. 2009), and their cleaning aggregations at isolated seamounts surrounded by deep oceanic waters (Marshall et al. 2009) suggest that they travel longer distances, tolerate cooler waters, and spend more time in or over deeper water compared to reef manta rays. Considering their offshore movements and less frequent observation by divers off Praia do Tofo, giant manta rays are thus likely to be less influenced by local variables than reef manta rays.

Whale sharks also undertake large-scale oceanic movements (Eckert \& Stewart 2001, Hsu et al. 2007, Rowat \& Gore 2007, Sleeman et al. 2010b), e.g. one whale shark that was satellite-tagged immediately adjacent to the current study area travelled $\sim 1200 \mathrm{~km}$ in 87 days (Brunnschweiler et al. 2009). Individual whale sharks at Praia do Tofo are generally seen for up to a few days before they move elsewhere (S. J. Pierce unpubl.). Similar to giant manta rays, their sightings at coastal sites are therefore likely to be driven more by broader-scale processes than local conditions. Other studies support this hypothesis, 

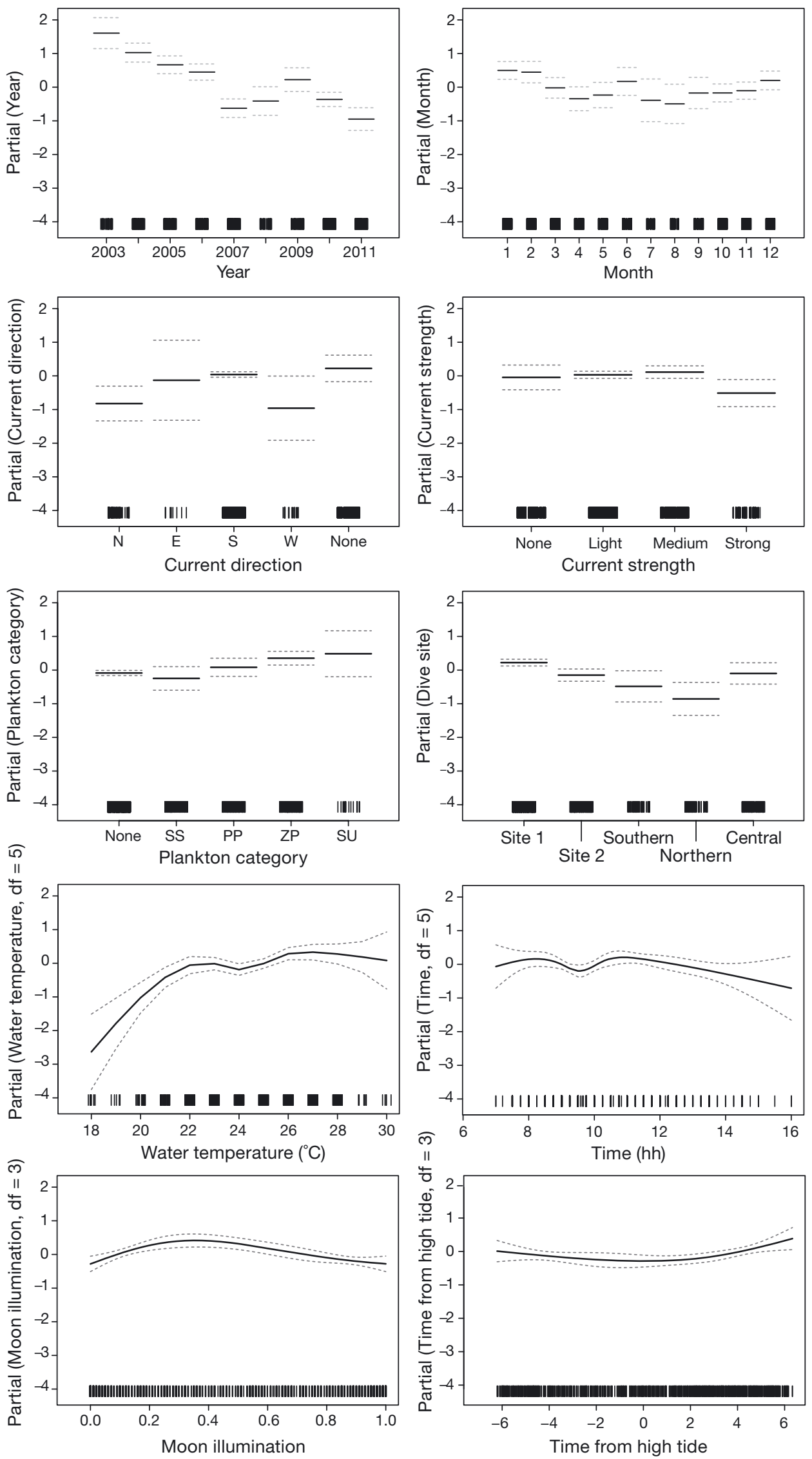

Fig. 3. Manta alfredi. Reef manta ray GLM model outputs showing the relationship between their sightings and all significant predictors. The rug plot along the $x$-axis indicates sampling effort and dotted lines mark the $95 \%$ confidence interval. See Table 1 for details 

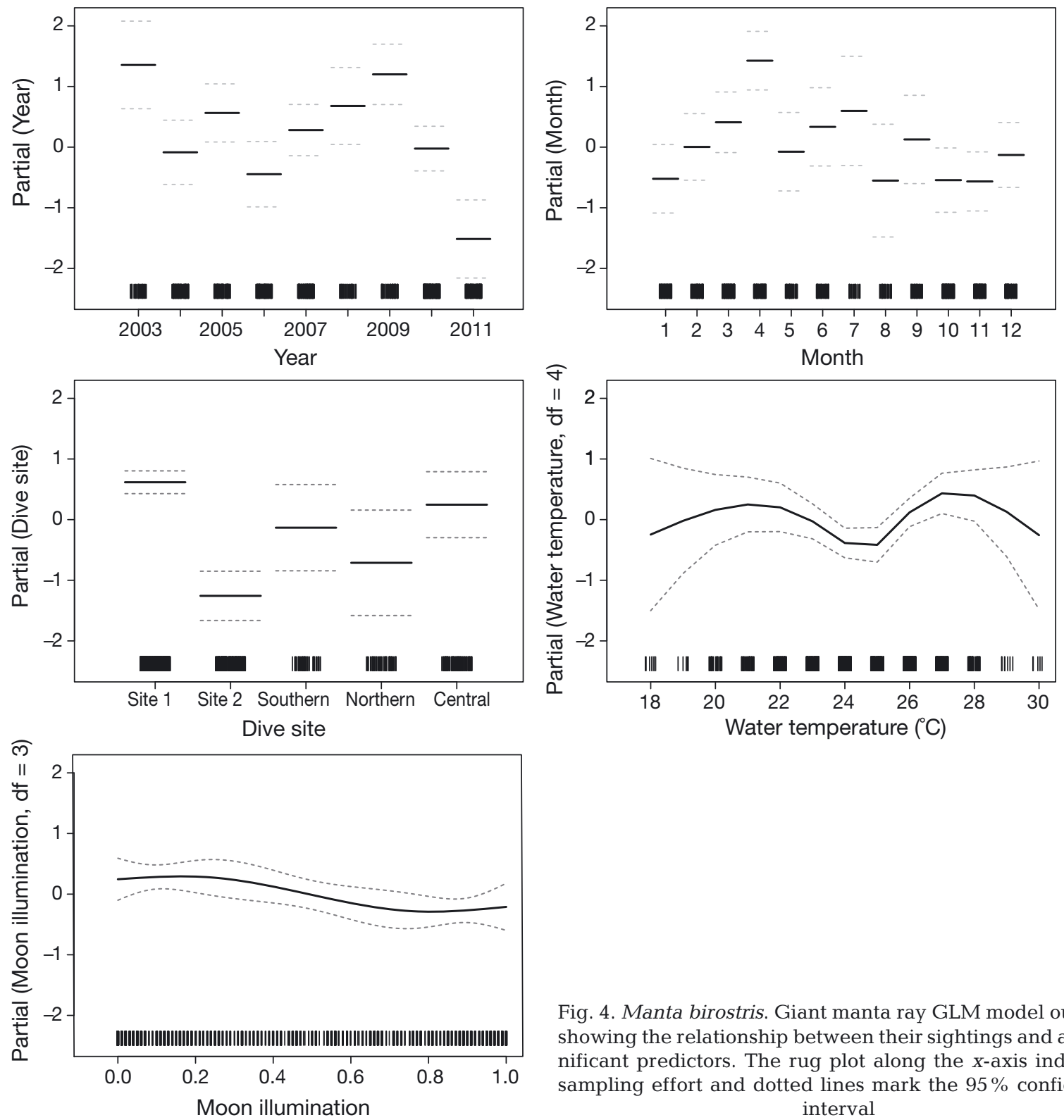

Fig. 4. Manta birostris. Giant manta ray GLM model outputs showing the relationship between their sightings and all significant predictors. The rug plot along the $x$-axis indicates sampling effort and dotted lines mark the $95 \%$ confidence interval

with sightings at Ningaloo Reef, Australia, partly linked to the Southern Oscillation Index that influences the strength of the Leeuwin Current (Wilson et al. 2001, Sleeman et al. 2010a).

\section{Declining sightings trends for reef manta rays and whale sharks}

Although sightings of giant manta rays were relatively stable over the study period, there was a significant decline in reef manta ray (88\%) and whale shark $(79 \%)$ sightings. By including various temporal and environmental variables in the GLM, the standardised sightings trend was adjusted for these variables. Although other local biophysical predictors not included in the GLM-may also influence sightings, external anthropogenic pressures or larger-scale oceanographic influences are likely to be involved. Reef manta rays are actively fished in southern Mozambique (Marshall et al. 2011b), with an estimated 20 to 50 individuals killed by fishers annually along the $50 \mathrm{~km}$ of coastline encompassing the present study area (A. D. Marshall unpubl.). This reef manta ray population is naturally small, as demonstrated in the superpopulation estimate of 802 

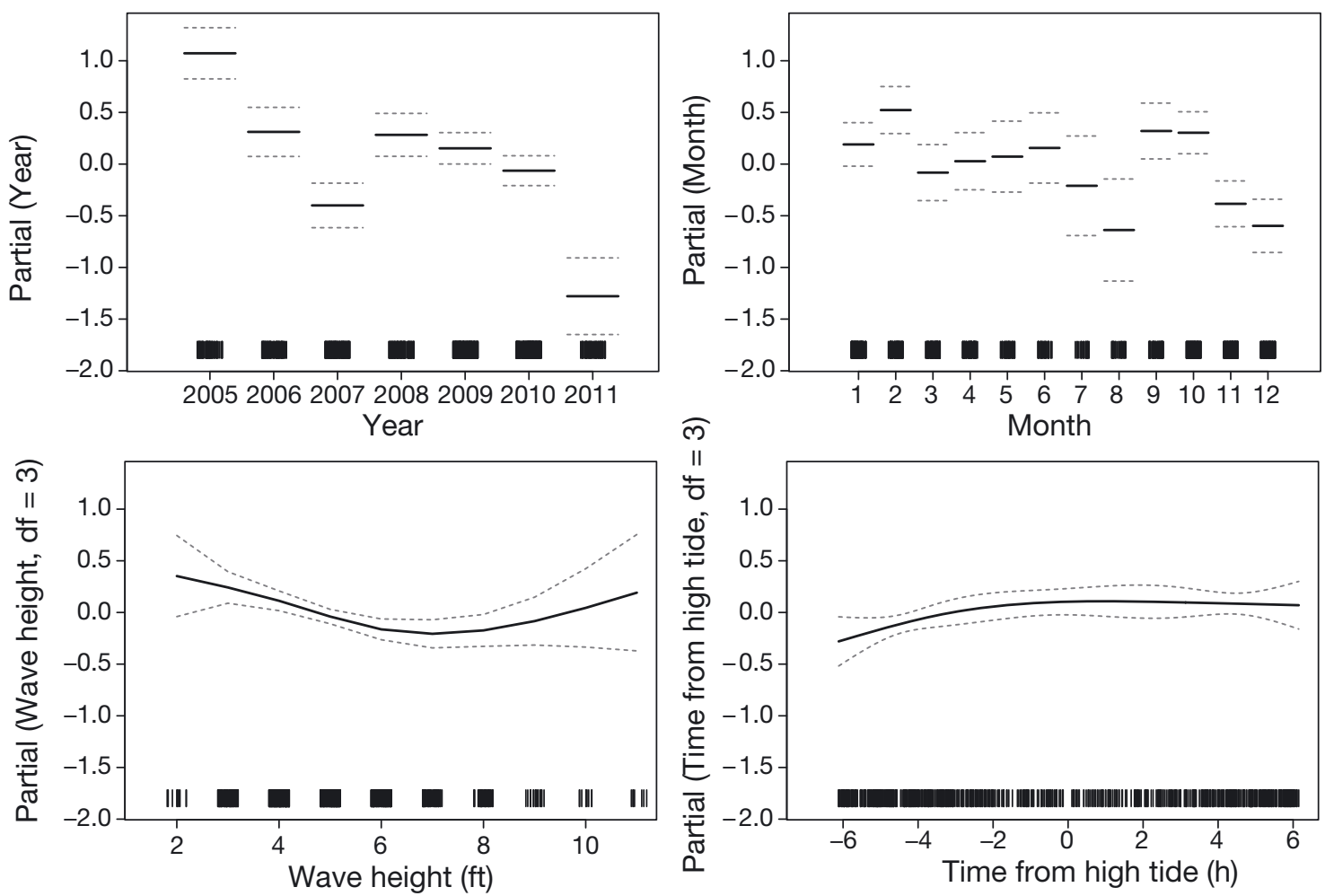

Fig. 5. Rhincodon typus. Whale shark GLM model outputs showing the relationship between their sightings and all significant predictors. The rug plot along the $x$-axis indicates sampling effort and dotted lines mark the $95 \%$ confidence interval

individuals in our study area, with annual population estimates ranging from 149 to 454 rays between 2003 and 2007 (Marshall et al. 2011b). As this species has a conservative life history strategy with a low level of recruitment, fishing pressure is likely to substantially impact this population (Marshall \& Bennett 2010b, Marshall et al. 2011b). Some of the reefs in the study area have also been increasingly subjected to SCUBA diving ecotourism pressure, with up to 11 regular commercial scuba diving operators, most with multiple boats, active in 2011 . Only 4 operators were active at the start of our study period, and the steady increase in diver traffic could interrupt cleaning activities and otherwise disturb the manta rays. Cleaning is an important daily activity and reef manta rays spend particularly long periods at cleaning stations in the present study area (Marshall 2009). Approximately $76 \%$ of individuals bear bite wounds of predatory sharks, and removal of dead tissue around injuries is thought to facilitate wound healing and prevent secondary infection (Marshall \& Bennett 2010a). Giant manta rays are less affected by bite injuries ( 35\%; Marshall 2009) and visit cleaning stations less regularly. As they spend less time at these reefs, they are likely to be less affected by the recreational diving activities that focus on these sites. Further, only one giant manta ray has been observed to be caught in the local fishery over the past 8 years (A. D. Marshall pers. obs.), suggesting that fishing pressure on this species is low in comparison to the reef manta ray.

A significant decline in whale shark sightings was also observed. There is no present-day fishery for whale sharks in Mozambique, although occasional catches have taken place in the local area during the study period (S. J. Pierce unpubl.). Tuna purse-seine fishers spot whale sharks in the Mozambique Channel (Sequeira et al. 2012) and their accidental catches could have negative impacts on the sharks (Floch et al. 2012). Also, some live sharks at Praia do Tofo bear scars attributable to net entanglement and propeller strikes (Speed et al. 2008). Given that whale sharks are capable of long-distance movements, it is plausible that negative human impacts elsewhere could affect sightings at Praia do Tofo, as has been suggested for this species at Ningaloo Reef, Australia (Bradshaw et al. 2007, 2008) and in the Andaman Sea, Thailand (Theberge \& Dearden 2006). Initial findings from the global whale shark database have shown little connectivity among distant aggregation 
sites in the Indian Ocean (Brooks et al. 2010, ECOCEAN 2012), and no link between sharks from Praia do Tofo and areas with active whale shark fisheries (such as Taiwan). However, the limited knowledge of whale shark movements in the Western Indian Ocean preclude a full assessment of this possibility (Gifford et al. 2007, Brunnschweiler et al. 2009, Brooks et al. 2010). Alternatively, regional- to largescale oceanographic parameters, not accounted for in our models, may also influence local whale shark sightings, as has been shown for Ningaloo Reef, Australia (Wilson et al. 2001, Sleeman et al. 2010a). Of particular importance may be the mesoscale eddies that dominate the flow of the Mozambique Channel (de Ruijter et al. 2002). These eddies exhibit high inter-annual variability (Schouten et al. 2003) and create strong fronts often associated with high biomass (Lima et al. 2002, Tew Kai \& Marsac 2010), suggesting that further investigation of mesoscale eddies will be important for understanding the strong interannual signal in whale shark sightings at Praia do Tofo.

\section{Is megafauna visitation seasonal?}

The model results suggested that the highest giant manta ray sightings were in April, although the $95 \%$ confidence limits do overlap with March and July. Such a pattern may imply an annual migration past Praia do Tofo during the austral autumn/winter, although additional sightings of giant manta rays were made throughout the year. Sightings of giant manta rays at other aggregation sites, such as south-eastern Brazil (Luiz et al. 2009) and New Zealand (Duffy \& Abbott 2003), similarly are seasonal and indicate that this species undertakes seasonal movements.

Reef manta rays were sighted throughout the year without exhibiting a clear seasonal signal. The model suggested higher sightings in the austral summer, although numbers from January/February were only significantly higher than April. More sightings in the austral summer are likely as this is when they mate and give birth in the study area (Marshall \& Bennett 2010b).

Whale sharks appear seasonally at most of their coastal aggregation sites around the world, with their visitation normally coinciding with increased prey availability (Taylor 1996, Nelson \& Eckert 2007, Riley et al. 2010, de la Parra Venegas et al. 2011, Rowat et al. 2011). The lack of a seasonal signal in whale shark sightings in this study indicates a departure from this general rule. Despite their non-seasonal appearance at Praia do Tofo, whale shark sightings fluctuated during the study. This is likely to be a consequence of their movement patterns and the variable local zooplankton abundance influenced by the dynamic regional oceanography dominated by event-scale, non-seasonal eddies (Schouten et al. 2003).

\section{Environmental influences on megafauna sightings}

Water temperature was a strongly significant predictor for reef manta rays, less so for giant manta rays, and SST was removed from the final model for whale sharks. Reef manta rays appeared to avoid cold water (18 to $\left.21^{\circ} \mathrm{C}\right)$, while giant manta rays had an unclear relationship with water temperature. The distribution of these 2 species overlap in parts of their range, but giant manta rays extend further into colder temperate areas (Kashiwagi et al. 2011, Couturier et al. 2012), which could explain why temperature is not as strong a predictor of their presence as it is for reef manta rays. Water temperatures on the reefs off Praia do Tofo fluctuated up to $7.5^{\circ} \mathrm{C} \mathrm{d}^{-1}$ (C. A. Rohner pers. obs.), with cool-water intrusions recorded in all seasons. Reef manta rays preferentially selected episodes of warmer water irrespective of season. Water temperature was not supported for the whale shark model. Whale sharks can tolerate cold waters, as they have a wide distribution extending into areas with cold surface waters (Turnbull \& Randell 2006) and can undertake deep dives into water as cold as $3.4^{\circ} \mathrm{C}$ (Brunnschweiler et al. 2009). In the western Indian Ocean, $90 \%$ of whale shark sightings have been suggested to occur in a narrow surface temperature band $\left(26.5\right.$ to $30^{\circ} \mathrm{C}$ ) (Sequeira et al. 2012). SST is likely to strongly influence whale shark sightings offshore, where fronts are a major driver of the spatial dynamics of predators (Zainuddin et al. 2008, Tew Kai \& Marsac 2010). The lack of a relationship with SST in our study was either because such oceanic fronts may have less influence on coastal surface waters, or because remotely sensed SST data was inadequate for our purpose.

Site 1 was the preferred reef for both manta ray species, while Site 2 was also often visited by the reef manta ray, but not the giant manta ray. Sightings of the latter were also marginally more common on southerly reefs than at Site 2 . Site 1 and the southern group are wide reefs that offer a large area for cleaning, while Site 2 is narrower and has relatively small cleaning stations. Giant manta rays, because of their large body size, may prefer larger reefs that enable them to remain close to cleaning stations, especially 
as they tend to get cleaned in groups, which may require more space to maneuver and alternate passes over the cleaning stations.

Minimum wave height impacted the sightings of whale sharks, with more individuals seen when waves were small. This may simply reflect an increase in sightability during these more favourable conditions rather than an actual change in whale shark presence or behaviour. Sharks may swim at greater depths when surface waters are rough and hence may be present, but not seen by surface-based observers (Rowat et al. 2009). Time from high tide had a weak effect on sightings of reef manta rays and whale sharks, with slightly more reef manta rays at low tide. Moon illumination was a supported predictor for both Manta species, with more sightings made when less than half the moon was illuminated. These results are in contrast with reef manta rays in Lombok, Indonesia, where their numbers increased during full and new moon when the tidal flux was highest (Dewar et al. 2008).

Significantly more reef manta rays were seen when zooplankton dominated the water column compared to when there was no plankton or when suspended sediment was present. Sediment-rich water could negatively affect normal gill ventilation for respiration and filter-feeding, and it is possible that large, mobile planktivores will avoid such conditions. Higher numbers of reef manta rays seen at cleaning stations when zooplankton was locally abundant may indicate that they preferentially visit cleaning stations that are in close proximity to good feeding areas.

Reef manta rays were sighted less frequently during northward currents compared to the predominant south- and eastward currents. Fewer reef manta rays were also seen in strong currents compared to medium and light currents, but were not significantly different from absent currents. We therefore interpret this relationship with caution. It appears that, given reef manta ray presence at the reefs was generally related to routine cleaning behaviour, this may indicate stronger currents are sub-optimal for cleaning. This is likely because it would be difficult for the small cleaner fishes to maintain their position above the reef in strong currents, or perhaps because reef manta rays preferentially avoid cleaning when it is energetically costly to hold their position relative to the reef. Time of day was marginally significant for reef manta rays, with a suggestive low in sightings from 08:30 to 10:00 h. This observation may reflect the relatively high amount of ecotourism boat traffic and diver numbers close to the reefs at those times.

\section{Broader applications and implications for conservation}

Praia do Tofo in southern Mozambique is one of the few coastal hotspots for all 3 species discussed in this study (Pierce et al. 2010, Marshall et al. 2011b). As whale sharks and manta rays are globally threatened, it is important to separate environmentally driven short-term fluctuations from significant longterm trends. This can be a challenge in these migratory species as sighting data are often from a single geographical locality within their broader range. Standardisation of catch data with multivariate models, which take into account a suite of environmental variables, has become common practice for fisheries managers (e.g. Agenbag et al. 2003, Zagaglia et al. 2004, Hazin \& Erzini 2008, Zainuddin et al. 2008) and here we have shown that GLMs are also a useful tool for examining sightings trends of planktivorous elasmobranchs. While, on a broad scale, changing ocean climate has the potential to shift historical aggregation sites through influencing environmental conditions and zooplankton composition and density, in this case sightings of $M$. birostris showed no significant trend in the limited study period. The observed data suggest a decline in sightings of reef manta rays and whale sharks, and this is confirmed by the GLM after taking into account a suite of local predictors in the model. While larger-scale oceanographic variables could drive the fluctuating numbers of whale shark sightings, the decline in sightings of reef manta rays may represent a true decline driven by mortality due to fishing or by avoidance of reefs visited by increasing numbers of dive tourists. However, the data in the present study do not unambiguously identify the reasons for an apparent decline in sightings of reef manta rays, but given that Praia do Tofo is a global hotspot for these species and also hosts a burgeoning marine tourism industry, potential threats such as increased fishing and tourism pressure require immediate attention by scientists and managers.

Acknowledgements. We thank W. N. Venables for his valuable input on the modelling and F. R. A. Jaine for productive discussions on the manuscript. MODIS satellite data were provided by NASA's Ocean Biology Processing Group. Casa Barry Lodge, Tofo Scuba, Peri-Peri Divers, Ocean Revolution, Project AWARE International and Fondation Ensemble supported fieldwork. S.J.P's work on this study was supported by the Swiss Shark Foundation, Rufford Small Grants and private donors. A.D.M's work was also supported by the Save Our Seas Foundation. Thanks to the many Marine Megafauna Association, All Out Africa and Quest Underseas staff and volunteers who helped with field work. 


\section{LITERATURE CITED}

Agenbag JJ, Richardson AJ, Demarcq H, Freon P, Weeks S, Shillington FA (2003) Estimating environmental preferences of South African pelagic fish species using catch size- and remote sensing data. Prog Oceanogr 59:275-300

Alava MNR, Dolumbalo ERZ, Yaptinchay AA, Trono RB (2002) Fishery and trade of whale sharks and manta rays in the Bohol Sea, Philippines. In: Fowler SL, Reed TM, Dipper FA (eds) Proc Elasmobranch Biodiversity, Conservation and Management: Proc Int Sem Work. Shark Specialist Group, IUCN, Gland, p 132-148

Anderson RC, Adam MS, Goes JI (2011) From monsoons to mantas: seasonal distribution of Manta alfredi in the Maldives. Fish Oceanogr 20:104-113

> Arzoumanian Z, Holmberg J, Norman B (2005) An astronomical pattern-matching algorithm for computer-aided identification of whale sharks, Rhincodon typus. J Appl Ecol 42:999-1011

Block BA, Jonsen ID, Jorgensen SJ, Winship AJ and others (2011) Tracking apex marine predator movements in a dynamic ocean. Nature 475:86-90

Boucher J, Ibanez F, Prieur L (1987) Daily and seasonal variations in the spatial distribution of zooplankton populations in relation to the physical structure in the Ligurian Sea front. J Mar Res 45:133-173

> Bradshaw CJA, Mollet HF, Meekan MG (2007) Inferring population trends for the world's largest fish from markrecapture estimates of survival. J Anim Ecol 76:480-489

> Bradshaw CJA, Fitzpatrick BM, Steinberg CC, Brook BW, Meekan MG (2008) Decline in whale shark size and abundance at Ningaloo Reef over the past decade: the world's largest fish is getting smaller. Biol Conserv 141: 1894-1905

Brooks K, Rowat D, Pierce SJ, Jouannet D, Vely M (2010) Seeing spots: photo-identification as a regional tool for whale shark identification. West Indian Ocean J Mar Sci 9:185-194

Brunnschweiler JM, Baensch H, Pierce SJ, Sims DW (2009) Deep-diving behaviour of a whale shark, Rhincodon typus, during long-distance movement in the western Indian Ocean. J Fish Biol 74:706-714

CITES (2002) CITES Appendix II nomination of the whale shark, Rhincodon typus. Proposal 12.35. CITES, Santiago

Cliff G, Anderson-Reade MD, Aitken AP, Charter GE, Peddemors VM (2007) Aerial census of whale sharks (Rhincodon typus) on the northern KwaZulu-Natal coast, South Africa. Fish Res 84:41-46

> Colin PL (1992) Reproduction of the Nassau grouper Epinephelus striatus (Pisces: Serranidae) and its relationship to environmental conditions. Environ Biol Fishes 34: 357-377

> Couturier LIE, Jaine FRA, Townsend KA, Weeks SJ, Richardson AJ, Bennett MB (2011) Distribution, site affinity and regional movements of the manta ray, Manta alfredi (Krefft, 1868), along the east coast of Australia. Mar Freshw Res 62:628-637

Couturier LIE, Marshall AD, Jaine FRA, Kashiwagi $\mathrm{T}$ and others (2012) Biology, ecology and conservation of the Mobulidae. J Fish Biol 80:1075-1119

> Deakos MH, Baker JD, Bejder L (2011) Characteristics of a manta ray Manta alfredi population off Maui, Hawaii, and implications for management. Mar Ecol Prog Ser 429:245-260 de la Parra Venegas R, Hueter RE, Gonzalez Cano J, Tyminski JP and others (2011) An unprecedented aggregation of whale sharks, Rhincodon typus, in Mexican coastal waters of the Caribbean Sea. PLoS ONE 6:e18994

de Ruijter WPM, Ridderinkhof H, Lutjeharms JRE, Schouten MW, Veth C (2002) Observations of the flow in the Mozambique Channel. Geophys Res Lett 29: 140-1-140-3, doi:10.1029/2001GL013714

Dewar H, Mous P, Domeier M, Muljadi A, Pet J, Whitty J (2008) Movements and site fidelity of the giant manta ray, Manta birostris, in the Komodo Marine Park, Indonesia. Mar Biol 155:121-133

Duffy CAJ, Abbott D (2003) Sightings of mobulid rays from northern New Zealand, with confirmation of the occurrence of Manta birostris in New Zealand waters. NZ J Mar Freshw Res 37:715-721

Eckert SA, Stewart BS (2001) Telemetry and satellite tracking of whale sharks, Rhincodon typus, in the Sea of Cortez, Mexico, and the north Pacific Ocean. Environ Biol Fishes 60:299-308

ECOCEAN (2012) Global whale shark photo-ID library. www.whaleshark.org

Flagg CN, Wirick CD, Smith SL (1994) The interaction of phytoplankton, zooplankton and currents from 15 months of continuous data in the Mid-Atlantic Bight. Deep-Sea Res II 41:411-435

Floch L, Chassot E, Damiano A, Fonteneau V and others (2012) Statistics of the French purse-seine fleet targeting tropical tunas in the Atlantic Ocean (1991-2010). Collective Volume of Scientific Papers, ICCAT 68:858-885

Gifford A, Compagno LJV, Levine M (2001) Aerial surveys of whale sharks (Rhincodon typus) off the east coast of southern Africa from 1993 to 1998. Report to the Shark Research Institute, Princeton, NJ, p 53-57

- Gifford A, Compagno LJV, Levine M, Antoniou A (2007) Satellite tracking of whale sharks using tethered tags. Fish Res 84:17-24

> Graham RT, Witt MJ, Castellanos DW, Remolina F, Maxwell S, Godley BJ, Hawkes LA (2012) Satellite tracking of manta rays highlights challenges to their conservation. PLoS ONE 7:e36834

> Hazin H, Erzini K (2008) Assessing swordfish distribution in the South Atlantic from spatial predictions. Fish Res 90: 45-55

Heyman WD, Kjerfve B (2008) Characterization of transient multi-species reef fish spawning aggregations at Gladden Spit, Belize. Bull Mar Sci 83:531-551

> Holmberg J, Norman B, Arzoumanian Z (2008) Robust, comparable population metrics through collaborative photomonitoring of whale sharks Rhincodon typus. Ecol Appl 18:222-233

> Holmberg J, Norman B, Arzoumanian Z (2009) Estimating population size, structure, and residency time for whale sharks Rhincodon typus through collaborative photoidentification. Endang Species Res 7:39-53

$>$ Hsu HH, Joung SJ, Liao YY, Liu KM (2007) Satellite tracking of juvenile whale sharks, Rhincodon typus, in the Northwestern Pacific. Fish Res 84:25-31

Hutchinson GE (1967) A treatise on limnology, Vol 2. Wiley, New York, NY

Kashiwagi T, Marshall AD, Bennett MB, Ovenden JR (2011) Habitat segregation and mosaic sympatry of the two species of manta ray in the Indian and Pacific Oceans: Manta alfredi and M. birostris. Mar Biodivers Rec 4:e53 
Lima ID, Olson DB, Doney SC (2002) Biological response to frontal dynamics and mesoscale variability in oligotrophic environments: biological production and community structure. J Geoph Res 107:C8, doi:10.1029/ 2000JC000393

Luiz OJJ, Balboni AP, Kodja G, Andrade M, Marum H (2009) Seasonal occurences of Manta birostris (Chondrichthyes: Mobulidae) in southeastern Brazil. Ichthyol Res 56:96-99

Marshall AD (2009) Biology and population ecology of Manta birostris in southern Mozambique. PhD thesis, The University of Queensland, St. Lucia

Marshall AD, Bennett MB (2010a) The frequency and effect of shark-inflicted bite injuries to the reef manta ray Manta alfredi. Afr J Mar Sci 32:573-580

Marshall AD, Bennett MB (2010b) Reproductive ecology of the reef manta ray Manta alfredi in southern Mozambique. J Fish Biol 77:169-190

Marshall AD, Compagno LJV, Bennett MB (2009) Redescription of the genus Manta with resurrection of Manta alfredi (Krefft, 1868) (Chondrichthyes; Myliobatoidei; Mobulidae). Zootaxa 2301:1-28

Marshall AD, Bennett MB, Kodja G, Hinojosa-Alvarez S and others (2011a) Manta birostris. In: IUCN red list of threatened species version 2012-1. www.iucnredlist.org/ details/198921/0 (accessed 24 Sep 2012)

- Marshall AD, Dudgeon CL, Bennett MB (2011b) Size and structure of a photographically identified population of manta rays Manta alfredi in southern Mozambique. Mar Biol 158:1111-1124

Marshall AD, Kashiwagi T, Bennett MB, Deakos MH and others (2011c) Manta alfredi. In: IUCN red list of threatened species version 2012-1. www. iucnredlist.org/ details/195459/0 (accessed 24 Sep 2012)

> Meekan MG, Bradshaw CJA, Press M, McLean C, Richards A, Quasnichka S, Taylor JG (2006) Population size and structure of whale sharks, Rhincodon typus, at Ningaloo Reef, Western Australia. Mar Ecol Prog Ser 319: 275-285

Nakaya K, Matsumoto R, Suda K (2008) Feeding strategy of the megamouth shark Megachasma pelagios (Lamniformes: Megachasmidae). J Fish Biol 73:17-34

Nelson JD, Eckert SA (2007) Foraging ecology of whale sharks (Rhincodon typus) within Bahia de Los Angeles, Baja California Norte, Mexico. Fish Res 84:47-64

Norman B (2005) Rhincodon typus. In: IUCN Red List of Threatened Species Version 2012-1. Available at www. iucnredlist.org/details/19488/0 (accessed 24 Sep 2012)

Parker HW, Stott FC (1965) Age, size and vertebra calcification in the basking shark Cetorhinus maximus (Gunnerus). Zool Mededeelingen 40:305-319

> Pierce SJ, Méndez-Jiménez A, Collins K, Rosero-Caicedo M, Monadjem A (2010) Developing a code of conduct for whale shark interactions in Mozambique. Aquat Conserv 20:782-788

Plourde S, Runge JA (1993) Reproduction of the planktonic copepod Calanus finmarchicus in the Lower St. Lawrence Estuary: relation to the cycle of phytoplankton production and evidence for a Calanus pump. Mar Ecol Prog Ser 102:217-227

Pravin P (2000) Whale shark in the Indian coast - need for conservation. Curr Sci 79:310-315

> Richardson AJ (2008) In hot water: zooplankton and climate change. ICES J Mar Sci 65:279-295

Richardson AJ, Schoeman DS (2004) Climate impact on plankton ecosystems in the Northeast Atlantic. Science 305:1609-1612

> Riley MJ, Hale MS, Harman A, Rees RG (2010) Analysis of whale shark Rhincodon typus aggregations near South Ari Atoll, Maldives Archipelago. Aquat Biol 8:145-150

Rowat D, Gore M (2007) Regional scale horizontal and local scale vertical movements of whale sharks in the Indian Ocean off Seychelles. Fish Res 84:32-40

Rowat D, Gore M, Meekan MG, Lawler IR, Bradshaw CJA (2009) Aerial survey as a tool to estimate whale shark abundance trends. J Exp Mar Biol Ecol 368:1-8

Rowat D, Brooks K, March A, McCarten C and others (2011) Long-term membership of whale sharks (Rhincodon typus) in coastal aggregations in Seychelles and Djibouti. Mar Freshw Res 62:621-627

Schouten MW, de Ruijter WPM, van Leeuwen PJ, Ridderinkhof H (2003) Eddies and variability in the Mozambique Channel. Deep-Sea Res II 50:1987-2003

Sequeira A, Mellin C, Rowat D, Meekan MG, Bradshaw CJA (2012) Ocean-scale prediction of whale shark distribution. Divers Distrib 18:504-518

Sims DW (2008) Sieving a living: a review of the biology, ecology and conservation status of the plankton-feeding basking shark Cetorhinus maximus. Adv Mar Biol 54: $171-220$

Sims DW, Reid PC (2002) Congruent trends in long-term zooplankton decline in the north-east Atlantic and basking shark (Cetorhinus maximus) fishery catches off west Ireland. Fish Oceanogr 11:59-63

Sleeman JC, Meekan MG, Wilson SG, Jenner CKS and others (2007) Biophysical correlates of relative abundances of marine megafauna at Ningaloo Reef, Western Australia. Mar Freshw Res 58:608-623

Sleeman JC, Meekan MG, Fitzpatrick BJ, Steinberg CR, Ancel R, Bradshaw CJA (2010a) Oceanographic and atmospheric phenomena influence the abundance of whale sharks at Ningaloo Reef, Western Australia. J Exp Mar Biol Ecol 382:77-81

Sleeman JC, Meekan MG, Wilson SG, Polovina JJ, Stevens JD, Boggs GS, Bradshaw CJA (2010b) To go or not to go with the flow: environmental influences on whale shark movement patterns. J Exp Mar Biol Ecol 390:84-98

Speed CW, Meekan MG, Rowat D, Pierce SJ, Marshall AD, Bradshaw CJA (2008) Scarring patterns and relative mortality rates of Indian Ocean whale sharks. J Fish Biol 72:1488-1503

Stevens JD (2007) Whale shark (Rhincodon typus) biology and ecology: a review of the primary literature. Fish Res 84:4-9

Taylor JG (1996) Seasonal occurrence, distribution and movements of the whale shark, Rhincodon typus, at Ningaloo Reef, Western Australia. Mar Freshw Res 47: 637-642

> Tew Kai E, Marsac F (2010) Influence of mesoscale eddies on spatial structuring of top predators' communities in the Mozambique Channel. Prog Oceanogr 86:214-223

> Theberge MM, Dearden P (2006) Detecting a decline in whale shark, Rhincodon typus, sightings in the Andaman Sea, Thailand using ecotourist operator-collected data. Oryx 40:337-342

- Turnbull SD, Randell JE (2006) Rare occurrence of a Rhincodon typus (whale shark) in the Bay of Fundy, Canada. Northeast Nat 13:57-58

van Duinkerken D (2010) Movements and site fidelity of the 
reef manta ray, Manta alfredi, along the coast of southern Mozambique. MSc thesis, Utrecht University

Venables WN, Ripley BD (2002) Modern applied statistics with S, 4th edn. Springer, New York, NY

> Ware DM, Thomson RE (2005) Bottom-up ecosystem trophic dynamics determine fish production in the Northeast Pacific. Science 308:1280-1284

- Wilson SG, Taylor JG, Pearce AF (2001) The seasonal aggregation of whale sharks at Ningaloo Reef, Western Australia: currents, migrations and the El Niño/Southern

Editorial responsibility: Matthias Seaman,

Oldendorf/Luhe, Germany
Oscillation. Environ Biol Fishes 61:1-11

Zagaglia CR, Lorenzzetti JA, Stech JL (2004) Remote sensing data and longline catches of yellowfin tuna (Thunnus albacares) in the equatorial Atlantic. Remote Sens Environ 93:267-281

Zainuddin M, Saitoh K, Saitoh SI (2008) Albacore (Thunnus alalunga) fishing ground in relation to oceanographic conditions in the western North Pacific Ocean using remotely sensed satellite data. Fish Oceanogr 17: $61-73$

Submitted: February 7, 2012; Accepted: January 28, 2013 Proofs received from author(s): April 29, 2013 